\title{
CURRENT OPINION
}

\section{Are there paternal components in human milk?}

\author{
Ahmed Ali Hassan (1), Zainab Taha (2), Abdullah Al Nafeesah (3), Ishag Adam (3) \\ (1) Faculty of Medicine, University of Khartoum, Sudan \\ (2) College of Natural and Health Sciences, Zayed University, United Arab Emirates \\ (3) Unaizah College of Medicine, Qassim University, Unaizah, Saudi Arabia
}

\begin{abstract}
Breastfeeding is indeed the foundation for life and gives growing children a once-ina-lifetime opportunity to grow and develop to their full potential. There are considerable studies on the role of maternal contribution to human milk components. It would be very important and interesting to explore the existence of a paternal contribution into the composition of human milk. Proceeding on this track, there is an abundant evidence that supports the hypothesis of paternal contribution in human milk composition. This evidence could be strengthened by the fact that a small population of the fetal cells migrate during pregnancy and stay for long time in the maternal body. This phenomenon is known as microchimerism. It has been well documented that some of these cells are of mature immunological and hematopoietic stem cells character. As the fetal parts contain $50 \%$ from each parent, any fetal parts in the maternal body (i.e., fetal microchimerism) should contain paternal components as well. The paternal genetic material is more responsible for the determination of the fetal sex (female XX or male XY). The variations
\end{abstract}

\section{Correspondence to:}

Prof Ishag Adam,

Unaizah College of Medicine, Qassim

University, Unaizah, Saudi Arabia

Email: ishagadam@hotmail.com

Received: 04 May 2019 | Accepted: 26 November 2019 in maternal human milk component that was clearly understood as related to child sex will substantially provide a solid basis for the investigation of the new hypothesis. In this short report, we conclude by briefly foregrounding the proposed role for paternal contribution on human milk composition for consideration and suggesting new directions for future research that would shed light on this subject.

\section{KEYWORDS}

Human milk; Maternal components; Paternal components; Breast milk.

Despite the extensive attention paid to the maternal components of human milk and its protective role of antibodies passed to the infants [1-4], our understanding of paternal components of human milk is still limited. The maternal component of human milk has been studied and the results have revealed that even nursing women (i.e., own child's mother or anyone else nursing the child) can transfer her genetic material, such as exosomes, stem cells (both pluripotent and multi-potent stem cells) and messenger RNA to the child through human milk $[5,6]$.

How to cite this article:

Hassan AA, Taha Z, Al Nafeesah A, Adam I. Are there paternal components in human milk? Sudan J Paediatr. 2019;19(2):84-87. https://doi.org/10.24911/SJP.106-1556954798 
Despite that fact that there is limited research and studies on the paternal component of breast milk, the transfer of cellular components from fathers to infants cannot be excluded. In this paper, we try to explain that human milk is not only attributed to maternal components, and that there is substantial evidence that human milk contains paternal components as well.

During pregnancy, small population of the fetal cells migrate and stay for a long time in the maternal body, a phenomenon known as microchimerism [7-10]. It has been well documented that some of these cells were of mature immunological and hematopoietic stem cells character [10]. As the fetal parts contain $50 \%$ from each parent, any fetal parts in the maternal body (i.e., fetal microchimerism) should contain paternal components as well. Recently, Wang et al. [11] discovered that among mouse embryos, paternal genome has a major influence on placental development. Therefore, in human beings, the possibility of having a considerable paternal contribution in the placenta, fetal microchimerism and the presence of paternal components in the human milk cannot be ruled out.

Moreover, paternal influence on human milk can even be traced from an earlier stage, as the paternal genetic material is more responsible for the determination of the fetal sex female (XX) or male (XY) [12]. The variations in maternal human milk component related to the child's sex have been documented in several studies [13-15]. For example, Powe et al. [13] found that mothers of male infants produced milk that had $25 \%$ greater energy content than mothers of female infants. Additionally, Y chromosomes were present in body (lung, spleen, liver, brain and the heart) of women pregnant with boys [8]. Some of the human milk stem cells expressed markers similar to those of embryonic stem cells such as TRA1-60, octamer-binding protein 4, NANOG and SOX2 [16]. Accordingly, and based on the fact that the Y chromosomes are of paternal origin, we can infer that the human milk stem cells may contain paternal components.

In humans, the major histocompatibility complex in mothers is not compatible with that of their offspring because of the duality of genetic chromosomal determination from both the mother and the father [17]. Therefore, the cellular component of human milk cannot be completely attributed and related to maternal side alone.

Infants usually acquire immunity through breast milk. Colostrum is the first milk a woman produces when she begins to breastfeed, and it contains large amounts of antibodies called 'secretory immunoglobulins'. Based on the above findings, it's possible to hypothesize that fathers can possibly share cellular components of human milk through their chromosomes.

According to the results of a study that addressed the correlation of polybrominated diphenyl ethers (PBDE) levels in maternal and paternal serum with age and sex, it has been found that PBDE congeners have the ability to cross the placental barrier, and prenatal and postnatal exposure to PBDEs is expected. Similarly, the hypothesized transfer of paternal cellular components to human milk could be investigated and evaluated [18].

The changes of human milk are reported between pregnant and non-pregnant lactating mothers [19]. For example, an overlap of breastfeeding during late pregnancy was found to be associated with differences in macronutrients and immunological components of milk [19]. Some beliefs exist in certain regions of the world, such as in Africa that sexual relations may contaminate the milk, and therefore a child should be weaned when the woman is pregnant again to avoid child illness [20-23]. Such beliefs need to be validated through scientific research.

The variations between human milk among different socioeconomic classes were documented $[24,25]$; hence, the father can affect the nutrition of the mother, through influencing the main family socioeconomic. Although certain maternal habits like smoking were found to be associated with lower lipid and protein concentrations in human milk [26], the impact of fathers` smoking on infant health through changing of breast milk has received less attention [27].

Several research questions still need to be raised and answered. For instance, does semen appear in the human milk after sex? and if so, is it harmful or beneficial to the infant? And what cellular or no cellular changes, if any, happen to the human 
milk? (i.e. cellular and non- cellular) does it affect the volume, the taste or the density of the milk? We also need to ask the question as to the role of paternal contribution on human milk stem cells (namely; their quantity, quality and origin) and what are the factors influencing them. The focus should not only be on the changes of human milk and sex after delivery but also before delivery. It would be interesting trying to find out whether there is any difference in the colostrum component between those women who had and those who did not have sex before delivery. Wet-nursing/crossnursing "the act of breastfeeding someone's else's child" and its various immunological aspect needs to be addressed in more depth in the future.

Furthermore, the prime focus should not only be exclusive to semen but also on the chemicals [28] and sexually transmitted diseases, such as viral hepatitis and human immunodeficiency virus infection which can be transmitted via semen.

\section{CONCLUSION}

It seems possible that some of the breast milk components are of paternal origin. Up until now, paternal components in human milk and its impact on infant health, have received less attention and more research is needed to explore this field.

\section{CONFLICT OF INTERESTS}

The authors declare that they have no competing interests.

\section{FUNDING}

None.

\section{ETHICS APPROVAL AND CONSENT TO PARTICIPATE}

Not applicable.

\section{REFERENCES}

1. Parmely MJ, Beer AE. Colostral cell-mediated immunity and the concept of a common secretory immune system. J Dairy Sci. 1977;60(4):655-65. https://doi.org/10.3168/jds.S0022-0302(77) 83915-5
2. Thorpe LW, Rudloff HE, Powell LC, Goldman AS. Decreased response of human milk leukocytes to chemoattractant peptides. Pediatr Res. 1986;20(4):373-7. https://doi. org/10.1203/00006450-198604000-00023

3. Twigger A-J, Hepworth AR, Tat Lai C, Chetwynd E, Stuebe AM, Blancafort $P$, et al. Gene expression in breastmilk cells is associated with maternal and infant characteristics. Sci Rep. 2015;5(1):1-14. https://doi.org/10.1038/srep12933

4. Kugananthan S, Gridneva Z, Lai CT, Hepworth AR, Mark PJ, Kakulas F, et al. Associations between maternal body composition and appetite hormones and macronutrients in human milk. Nutrients. 2017;9(3). https://doi.org/10.3390/ nu9030252

5. Peterson MB. The presence of stem cells in human breast milk and research implications [cited 2019 Dec 2]. Available from: https:// digitalcommons.liberty.edu/cgi/viewcontent. cgi?article $=1630 \&$ context=honors.

6. Wilson L. Nutrition and breastfeeding - the longterm impact of breastmilk on health [cited 2019 Dec 2]. Available from: http://motherjourney. com/uploads/3/5/3/1/35315324/epigenetics_ and_breastfeeding_article.pdf.

7. Molès JP, Tuaillon E, Kankasa C, Bedin AS, Nagot $\mathrm{N}$, Marchant $A$, et al. Breastfeeding-related maternal microchimerism. Nat Rev Immunol. 2017;17(11):729-1. https://doi.org/10.1038/ nri.2017.115

8. Minai-Tehrani A, Amini M, Gilany K. Existence of microchimerism in pregnant women carrying a boy! J Reprod Infertil. 2016;17(1):64-5.

9. Rumyantsev AG, Kurcer MA, Mareeva JM, Misjurin AV, Roumiantsev SA, Ustjugov AJ. Clinical significance of the fetal microchimerism for mother. Cell Transplant Tissue Eng. 2012;7(2):103-11.

10. Kanold AM. Maternal microchimerism. Stockholm, Sweden: Karolinska Institutet; 2013.

11. Wang X, Miller DC, Harman R, Antczak DF, Clark AG. Paternally expressed genes predominate in the placenta. Proc Natl Acad Sci. 2013;110(26):1070510. https://doi.org/10.1073/pnas.1308998110

12. Newcastle University. Boy or girl? It's in the father's genes. Science Daily. 2008;1-5 [cited 2019 Oct 2].

13. Powe CE, Knott CD, Conklin-Brittain N. Infant sex predicts breast milk energy content. Am J Hum Biol. 2010;22:50-4. https://doi.org/10.1002/ ajhb.20941

14. Galante L, Milan A, Reynolds C, Cameron-Smith D, Vickers M, Pundir S. Sex-Specific Human Milk 
Composition: the role of infant sex in determining early life nutrition. Nutrients. 2018;10(9):1-11. https://doi.org/10.3390/nu10091194

15. Stam J, Sauer PJJ, Boehm G. Can we define an infant's need from the composition of human milk ? Am J Clin Nutr. 2013;98(suppl) C:521S-8S. https://doi.org/10.3945/ajcn.112.044370

16. Sani M, Hosseini SM, Salmannejad M, Aleahmad F, Ebrahimi S, Jahanshahi S, et al. Origins of the breast milk-derived cells; an endeavor to find the cell sources. Cell Biol Int. 2015;39:611-8. https:// doi.org/10.1002/cbin.10432

17. Cabinian A, Sinsimer D, Tang M, Zumba O, Mehta $\mathrm{H}$, Toma $\mathrm{A}$, et al. Transfer of maternal immune cells by breastfeeding: Maternal cytotoxic $t$ lymphocytes present in breast milk localize in the peyer's patches of the nursed infant. PLoS One. 2016;11(6):1-18. https://doi.org/10.1371/ journal.pone.0156762

18. Gómara B, Herrero L, Ramos JJ, Mateo JR, Fernández MA, García JF, et al. Distribution of polybrominated diphenyl ethers in human umbilical cord serum, paternal serum, maternal serum, placentas, and breast milk from madrid population, Spain. Environ Sci Technol. 2007;41(20):6961-8. https://doi.org/10.1021/ es0714484

19. Marquins GS, Penny ME, Zimmmer JP, Diaz JM, Martin RM. An overlap of breastfeeding during late pregnancy is associated with subsequent changes in colostrum composition and morbidity rates among Peruvian infants and their mothers. J Nutr. 2003;133(8):2585-91. https://doi. org/10.1093/jn/133.8.2585

20. Haroun HM, Mahfouz MS, Ibrahim BY. Breast feeding indicators in Sudan : a case study of Wad
Medani town. Sudan J Public Heal. 2008;3:81-90.

21. Walle E van de: Walle F van de. Breastfeeding and popular aetiology. Heal Transit Rev. 1991;1(1): 1-12.

22. McMahon SA, George AS, Yumkella F, Diaz T. Spoiled breast milk and bad water; Local understandings of diarrhea causes and prevention in rural Sierra Leone. BMC Public Health. 2013;13(1172). https://doi.org/10.1186/14712458-13-1172

23. Daglas M, Antoniou E. Cultural views and practices related to breastfeeding. Heal Sci J. 2012;6(2):353-61.

24. National Academy of Sciences. Nutrition during lactation. Washington, DC; 1991 [cited 2019 Oct 20].

25. Nayak U, Kanungo S, Zhang D, Ross Colgate $E$, Carmolli MP, Dey A, et al. Influence of maternal and socioeconomic factors on breast milk fatty acid composition in urban, low-income families. Matern Child Nutr. 2017;April 2016:1-11. https:// doi.org/10.1111/mcn.12423

26. Bachour P, Yafawi R, Jaber F, Choueiri E, AbdelRazzak Z. Effects of smoking, mother's age, body mass index, and parity number on lipid, protein, and secretory immunoglobulin a concentrations of human milk. Breastfeed Med. 2012;7(3):17988. https://doi.org/10.1089/bfm.2011.0038

27. Blackburn CM, Bonas S, Spencer NJ, Coe CJ, Dolan A, Moy R. Parental smoking and passive smoking in infants: Fathers matter too. Health Educ Res. 2005;20:185-94. https://doi.org/10.1093/her/ cyg117

28. Van Esterik P. Breastfeeding in a contaminated environment. Can Women's Heal Netw. 2006;6/7 4/1:1-5. 